\title{
The Impact of International Labor Migration on Business Activities
}

\author{
Assem Ehamd ${ }^{1}$ \\ ${ }^{1}$ Vilnius University, Lithuania \\ Correspondence: Assem Ehamd, Vilnius University, Lithuania. E-mail: assem255@hotmail.com \\ Received: October 9, 2021 \\ Accepted: December 27, $2021 \quad$ Online Published: January 9, 2022 \\ doi:10.5539/ijbm.v17n2p28 \\ URL: https://doi.org/10.5539/ijbm.v17n2p28
}

\begin{abstract}
Labor migration has gained momentum and has become an intensive and difficult process to manage. The problem of emigration is evidenced by the particularly high flows of people leaving to work and live abroad (Akerman, 2007). As migration processes intensify, there are risks of an economic, socio-cultural and political-managerial nature. Population migration takes place in all countries of the world, but the extent of population migration and the impact on the country's economy and business vary. The work summarizes the theories and concepts of international labor migration, explains the causes of international labor migration and the positive and negative consequences for business. Two countries were selected to assess international labor migration impact on businesses activities. Lithuania was the first choice because its economic and political and institutional and technological was growing from time to time. Egypt was the second choice because it was suffereing after the two revolutions and its indicators had negatively affected except technological sector . The business environment of selected countries were examined. The business environment of selected countries was also examined, and the impact of international labor migration on the activities of companies was determined (Böcker, 2019).
\end{abstract}

Keywords: skills and Knowledge impact on Business activities, The negative and positive effects of Migration, The links between international labor migration and business activities

\section{Introduction}

The relevance of the topic is represented in explaining one of the most important and prevailing phenomenon of international labor migration and providing the explanation of the migration theories and explaining the importance of examining the impact and the link of international labor migration on the business activities for discovering what are the advantages that will help the host countries in improving business environment and end the most essential problem that the host countries are suffering from it, which is labor shortage .Examining the phenomenon of the international labor migration will additionally reveal the disadvantages of the international labor migration that could cause a damage in the economy of the host countries on the long-term specially if the international labor migration is over increased in the host countries (Akerman, 2007).

The aim of the article is to investigate the impact of international labor migration on business activities internationally, and providing examples about Canada and UK. The problem investigation level of the article is focusing on the researchers from different fields that provided the concept of migration, the determinants of migration, and the causes and trends of migration. It's very essential to examine the impact of international labor migration to know how the that will help the host countries in improving business environment and end the most essential problem which is labor shortage .Examining the phenomenon of the international labor migration will discover the disadvantages of the international labor migration that could cause a damage in the economy of the host countries specially if the international labor migration is over increased in the host countries (Collyer,2006). The essence and the object of the problem is about how does international labor migration influence business activities.

The objectives of the article are:

1. To summarize the concept and theories of international labor migration.

2. To describe the causes and consequences of labor migration.

3. To discuss the importance of the business environment for business activities. 
4. To identify the links between international labor migration and business activities.

The structure of the Article is organized as follow. The first chapter will introduce the different theories and concepts of the international labor migration, and the explaining the causes and the positive and negative consequences of the international labor migration on the business in the origin and destination countries.

The second chapter in the article will explain what are the impact of international labor migration on the business activities.

The third chapter will explain the links between the international labor migration and business activities, and there will be a comparison between Lithuania and Egypt. There will be a survey made by professors from the British university in Egypt and from Vilnius university and from Business men in Lithuania, and the survey will explain the expression of the professors and the business men about the importance level of the economic indicators and the institutional factors and social factors and cultural factors of the Lithuania and Egypt.

The article and research methods are represented in using the analysis and synthesis of scientific literature for analyzing the different theories and concepts and explaining the causes and consequences of international labor migration and impact on the business. The research uses a survey from experts, the analysis and summary of statistic data, and the research also use two models in the analytical and the theoretical parts.

Literature used in the article is represented in the theoretical part of the article mainly used works by the scientific articles and literature of the different authors.

The theoretical significance of this article is represented in using the analysis of the different scientific articles and journals of the different authors for evaluating the different causes and the positive and negative consequences of the international labor migration on the business in the origin and destination countries, and also the significance of the article is represented in the identifying and explaining the link between the international labor migration and business, and there is a model that is provided to explain the link between the business in the origin and destination countries and the international labor migration.

The practical significance of the article is to assess practically the positive impact and the improvement of the international labor migration on the receiving business environment and on the sending business environment and there will be countries will be practically examined by sending questionnaires to a number of experts in those two countries to practically assess the impact of the international labor migration on the business environment of both countries one is a receiving country and the other is a sending country.

Authorization of results gained from attending the conference 15th Prof. Vladas Gronskas International Scientific Conference on 3 of December 2020 for presenting the topic of international labour migration causes and tendencies.

The structure and scope of the article consists of an introduction, theoretical part, and analytical part and conclusions. The study is presented in 34 pages, including 4 tables and 6 figures. The list of references consists of 24 references.

\section{Theoretical Aspects of Impact of International Labor Migration on Business}

This chapter provides an overview of the concept and theories of the international labor migration,

\subsection{The Concept and the Theories of International Labor Migration}

Definitions of migration vary depending on the context - political, social and economic. However, in any case, the two most important criteria remain in the definition of migration, namely the change of space - place of residence, and the relocation of time for a certain period of time (Bratsberg et al., 2019). Some definitions of migration are given in Figure 1. 


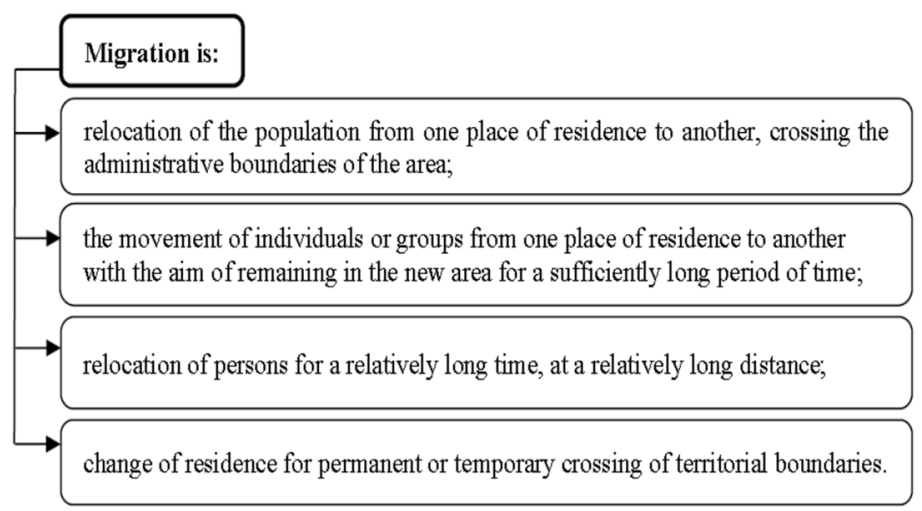

Figure 1. Definition of migration

Source: created by the authors according to Damulienè, A. (2013). Migracijos problema Lietuvoje ir jos ịtaka šalies ekonomikai, p. 107.

In summary, migration is understood as the relocation of an individual to another country with two main criteria: spatial (change of residence) and time (relocation for a certain period of time) dimensions.

A number of theories have been advanced in the literature to explain the factors that influence the decision to migrate.

Migration theories are classified based on different perspectives (Table 2).

Table 1. The migration theories

\begin{tabular}{ll}
\hline Theories & Description \\
\hline The neoclassical theory & This theory suppose that labor markets and economies move towards equilibrium in the long- run \\
within trade and migration. It looks at and considers migrants as purely rational actors. \\
The new economics theory \\
This theory merges the societal dimension in the decision to migrate. The migration decision is \\
usually conducted collectively, especially within households. \\
According to this theory, the demand for labor in developed economies pulls migrants independently \\
from the labor or wage conditions at the origin societies. At the receiving economy, the labor market \\
is segmented. \\
This theory is defined as a bunch of interpersonal ties that relate migrants, with relatives, friends or \\
fellow countrymen at home who convey information, give financial backups, and facilitate \\
employment opportunities and accommodation in various supportive ways. \\
Thetwork theory \\
This theory focuses on the nexus between people at origin and destination. Migratory movements are \\
often connected to prior long-standing links between sending and receiving countries. \\
According to this theory, organizations that developed alongside international migration started to \\
play a role in nurturing and encouraging further migration. \\
The World system theory is putting emphasize on migration from peripheral developing countries to \\
core capitalist ones. Migrants come I large amount from the periphery to the core while capital, \\
machinery, and goods come from the core to the periphery. \\
The world theory
\end{tabular}

In summary, it can be stated that scientists focus on slightly different but interrelated reasons for the decision to migrate. At present, there is no single, coherent theory of international migration, which could explain all reasons for migration.

\subsection{Causes of International Labor Migration}

Demand-pull factors and Supply-push factors for labor. Demand-pull factor:

- Better education facilities: developing the education system, and providing the subsidies for supporting the 
different academic researches and to build more universities and more experimental labs and build more schools (Borjas ,2019).

- Better medical facilities: improving all the medical facilities and spending on providing all the doctors and the nurses and all the members of the medical staff all the required free training programs to improve the quality of their performance (Arango,2007).

- National prestige: any country that want to develop itself will improve its infrastructure and its education system and its medical system and improve its army to have a strong national prestige and that will attract all the different migrants. (Abreu,2018)

- Better behavior among people: the countries that want to have a respective reputation must pay attention for making a high-quality education free system for all people and that will contribute in making all the people be educative and that will help them to deal each other respectively and to deal with the other strangers respectively (Collyer, 2006).

- Religious tolerance: The countries that accept the different religions and gives the freedom of practicing the religion rituals.

- Family reasons: giving the right for family reunification and provide them with the suitable social assistance.

Supply-push factors in the origin area. Various social, political and economic forces in the place of destination impel people to do so.

- War or other armed conflict: All kinds of war in any country result in making unsafe environment for all migrants.

- Famine or drought: Famine and drought are considered the two important factors that are making the countries suffering from the shortage of food and water

- Poverty: Poverty that is resulted from the economic growth decline and increase migration

- Political corruption: Persecution because of one's ethnicity, religion, race, politics or culture can push people to leave their country.

- Religious fundamentalism or religious intolerance: The discrimination against religion in any country make the inside that country decide to leave it

- Lack of employment opportunities: the different dangerous economic problems like the high inflation rate and the high interest rate on the loans increase unemployment and migration

- Lack of various rights: the lack of freedom of opinion expression and the lack of taking the full financial rights during or after finishing the work.

- Natural disasters: Natural disasters destroy all the business enterprises products and properties and that will make provide unsafe environment

- Income differentials and income inequality

The inequality of income distribution in the jobs will increase migration phenomenon (Massey, 2004).

\subsection{The Consequences of International Labor Migration}

The negative effects of labor migration on origin countries. Among the negative effects of migration for countries of origin is the fact that a significant part of the highly skilled workforce is lost. By emigrating qualified staff, the home state can no longer benefit from the results of investing in the training and qualification of human resources, the cost of which is an expense that it no longer recovers. Countries that have a big number of labor immigration rate will have many problems, because the high rate of labor migration will make the business companies achieve low rate of productivity and that will stop the growth of the economy of these countries. The foreign investors do not want to invest in these countries and that will reduce will affect negatively on the economy (Borjas,2019).

\subsubsection{Positive Impacts of the Labor Migration of the International Labor Migration on the Origin Countries}

Remittances are considered the second largest source of external funding for developing countries, and it's used for economic reforms and for making investments. Remittances (money transfers of emigrants) have important positive effects for the national economy because

-Increase internal demand for goods and services, thus becoming a growth factor;

-Increase monetary flow; 
-Contribute to improving the balance of payments and foreign currency reserves of the country (thus allowing for higher imports and more substantial development loans);

- Contribute to reducing the cost of money (exchange rate and interest rate, which means more credit for consumption and investment);

-Lead to increasing the standard of living of those concerned and their families, long-term and indirectly of the entire population (Clemens, 2004).

\subsubsection{Positive Effects of the International Labor Migration on the Destination Countries}

Increased economic output and living standards. Net immigration will lead to a growth in the size of the labor force and an increase in the productive capacity of the economy. Immigration leads to higher economic growth with a corresponding rise in tax revenues and potential for government spending. The international labor migration will help in providing a solution for skilled labor shortage, by providing more foreign skilled labor for filling the job vacancies in all the different fields, and also all the unpopular jobs will be filled by those foreign labor (Ahmed,2012).

\subsubsection{The Negative Effects of International Labor Migration on the Destination Countries}

There are negative effects on the international companies and the local companies in the host countries and these negative effects will be represented in the big amount of money that these company will spend them on providing an effective intensive training and language programs to make the foreign labor effective in their working tasks and in speaking the native languages because the foreign labor will have an educational degrees from their developing countries and these educational degrees of the foreign labor will not match the work requirements in the international and local companies, and these big and heavy expenses will reduce the profit of the international companies and the local companies of the host countries. which that will restrict the big expansion of the different business activities of international companies and the local companies in the developed countries on the long-term, and that will mean that these companies in the developed countries will not be able to provide more job opportunities for more local and foreign labors in the developing countries. Some international labor might have not the ability to adapt to the native culture of the foreign countries that they are working in them, and that will not make them achieve great results in their work (Bratsberg et al., 2007).

\subsection{The Links between International Labor Migration and Business Environment}

The business environment is the climate or set of conditions-economic, political or institutional conditions in which business operations are conducted. the business environment is related to the economic activities of the person (entrepreneur) like trade, commerce, industries, and direct services, and the business environment is the dynamic because The components of the environment are also subject to change according to the country timings, circumstances, and the economic conditions.

Migrants and Entrepreneurs must have a proper understanding of the political, legal and economic environment which that helps in identifying the proper country for migration and investment.

Assessing the Business from economical perspective. The most important indicators for assessing the business environment for all migrants are the unemployment rate and the inflation rate and the exchange rates and GDP and the productivity rate and the price policy and the monetary policy of the target country (Collyer, 2006).

Assessing the business environment from the legal perspective. The migrants must know the legal rules that regulate the life and the business and working activities (Bratsberg et al., 2007).

Assessing the Business environment from the political perspective. The foreign entrepreneurs must pay attention for evaluating the political stability of the target country for stability settlement

Assessing the Business environment from the cultural perspective. The entrepreneurs must pay attention for gathering information about the culture and the traditions and the customs of the target country for dealing with natives more properly (Akerman, 2007).

Summarizing the above analysis of scientific literature, it can be created the theoretical model of the impact of international labor migration on business (Figure 2). 


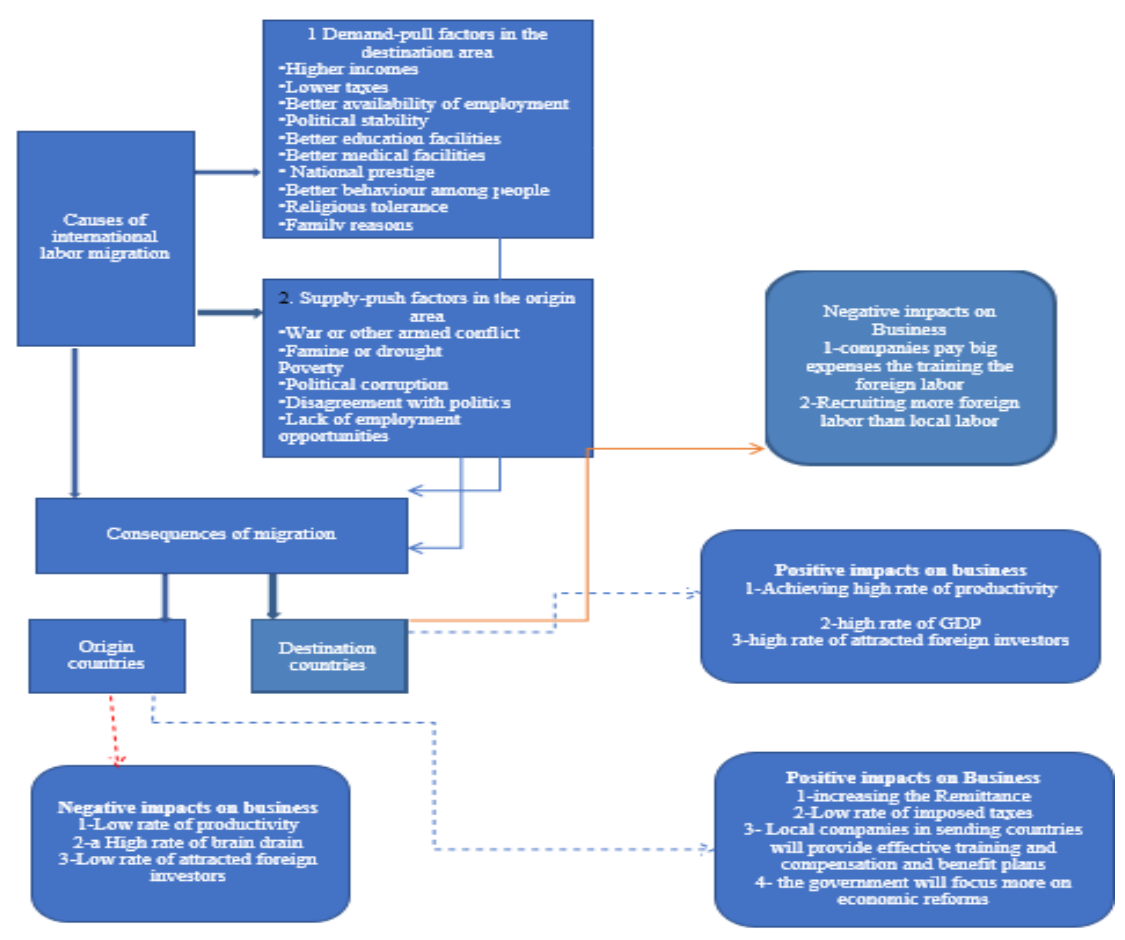

Figure 2. The research model of the impact of international labor migration on business activities

This model explains the Demand-pull and supply-push factors and attract the foreign labor to destination countries of international labor migration and the supply-push factors that will make the local labor decide to migrate from the origin area to destination areas.

\section{Literature Review of Impact of International Labor Migration on Business Activities (Material and Methods)}

\subsection{Research on the Impact of International Labor Migration on Business Activities}

According to Böcker 2019. The rapid growth in the foreign-born population in many developing countries in the recent decades has prompted considerable research on the socio-economic impacts of immigration. Among this research activity there have been a number of econometric studies conducted since the 1990s that suggest that immigration has a statistically significant positive impact on merchandise trade (Akerman,2007).

International labor migration impact on economy. According to Cowen,2019. International labor migration has a great impact on the productivity rate and increasing the GDP of economy of receiving countries and there is a great example that is represented in Canada that has long been a country of net immigration and Canada has long been a country of net immigration and has designed its current immigration policy around attracting highly educated and skilled migrants for entry into its labor force. the initial impact of migrants' arrival upon the host country's economy de-pends upon a number of circumstances. the employability and productivity of migrants depends upon how well their skill profiles match the demands of employer (Clark et al., 2007). A few countries, including Australia and Canada, have adopted a point scheme to filter acceptable immigrants in an effort to enhance the likelihood of job matching. Foreign labor can enhance the economy by filling the shortage in all International labor migration has a great impact on the productivity rate and increasing the GDP of economy of receiving countries and there is a great example that is represented in Canada that has long been a country of net immigration and Canada has long been a country of net immigration and has designed its current immigration policy around attracting highly educated and skilled migrants for entry into its labor force. the initial impact of migrants' arrival upon the host country's economy de-pends upon a number of circumstances. the employability and productivity of migrants depends upon how well their skill profiles match the demands of employers. A few countries, including Australia and Canada, have adopted a point scheme to filter acceptable immigrants in an effort to enhance the likelihood of job matching. Foreign labor can enhance the economy by filling the shortage in all the business sectors and making them working continuously and making the Canadian government continue to impose taxes on all these business sectors and the Canadian government will use the earned money 
in improving the infrastructure of Canada and improving the education and health and the defense system. The sending countries will negatively be affected by the international labor migration because the productivity rate will be decreased because a big percentage of skilled workers decided to migrate from the sending countries and their experiences and skills and their innovation that is existed in them in different percentages will be not usel for the sending countries and useful for the receiving countries (Aydemir \& Robinson,2020).

Impact of international labor migration on Achieving innovation. Much of the literature examining immigrant impacts on innovation focuses on the US with only limited evidence available for the UK. For the US, Cowen (2019) find that highly skilled immigrants increase the number of patents registered without crowding out natives. They also suggest that as well as contributing directly to innovation through research, immigrants may provide positive spillovers to their research colleagues and by providing complementary skills. Clemens (2004) find that $65 \%$ of the increase in the number of scientists and engineers in the US was due to foreign born individuals, between 1995 and 2006. For the UK, Brücker and Schröder (2019) finds a causal link between immigration and innovation. She finds that "skilled immigration is a significant determinant of local innovative performance in Britain".

Migrant skills impact on Business activities. According to Abreu (2018) Skills held by migrant workers allowed businesses to expand their workforce, to fulfil existing contracts and to take on more work. In one aerospace consultancy they were heavily reliant on recruiting outside the UK for highly specialized engineering roles, as migrants were needed to meet their growth potential. "The people that we need are not available in the UK. There is not the capability within the UK any longer to meet our aspirations." (Manager, Aerospace, Bristol, 5-10\% migrants, Large) (Collier\& Hoeffler, 2019). For other businesses, migrants added something above and beyond, or different to, equivalent UK applicants. This allowed businesses to access a wider talent pool than would be available without migrants, which allowed the business to select better candidates.

Migrants transferring knowledge about specific processes or products from other settings. According to Castles (2003) in a creative environment within an international market that demands international players, migrants bring specialist knowledge and experience that help them develop new processes and offered a different way of approaching and solving problems. They translated some practices and shared knowledge with co-workers, but also created process efficiencies that brought time and cost savings to the business. Migrant workers in New Zealand enhanced the skills of people in new Zealand in Budgeting and costing skills in a slow way as native people are reserving a third of their rendering time in processing the data that are needed for budgeting and calculating the required costs and the processing of the required data is too slow with native people in new Zealand, the migrant from south Korea have the skills that enable them to do an accurate budget and determine the required costs for any production process in a faster way than the native people in new Zealand, and they can learn the native people in new Zealand and that can make the new Zealand people be able to set an accurate budget for making a profitable production process, with cheaper costs, and has a huge knock-on effect. (Ahmed, 2012).

\subsubsection{The Negative Effects of Immigration on the International Business}

The Unemployment may rise if there are unrestricted numbers of migrants, and Depression of wages may occur, especially in lower paid jobs. Having workers willing to work for relatively low pay may allow employers to ignore productivity, training and innovation (Cazzuffi \& Modrego,2018)

\subsection{Research Model of Impact of International Labor Migration on Business Activities}

In the present analytical framework, the impact of the international labor migration is constructed in the model and also the research model will explain the link of the international labor migration and business activities, and the model will explain the Economic and social and cultural and institutional and technological Indicators that have a strong impact on increasing or decreasing the international labor migration to any country. 


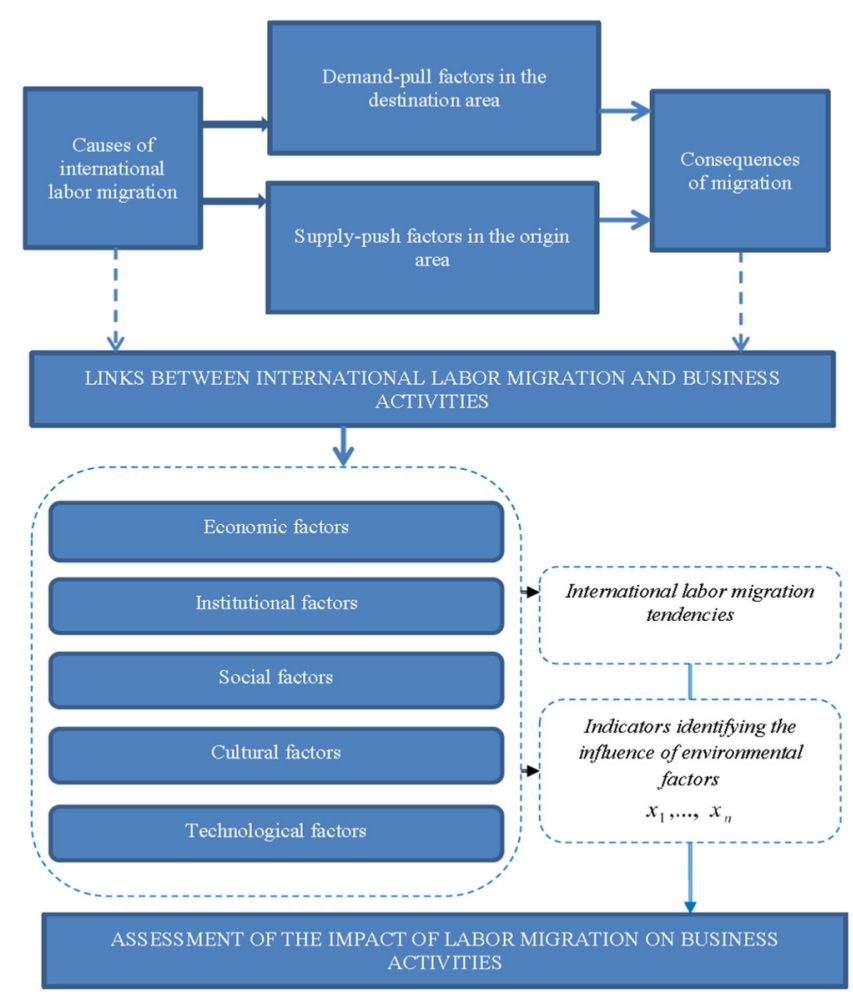

Figure 3. The research model of the impact of international labor migration on business activities

\subsection{Method and Analysis (Research Methodology)}

Two countries were selected to assess international labor migration impact on businesses activities. Lithuania was the first choice because its economy is growing from time to time since it became a member in the european union and start to attract more migrants from time to time. Egypt was the second choice because the economy of Egypt was suffereing alot after the two revolutions and the economic and the institutional indicators had negatively affected and the country has only improved technological sector and it has a high immigration level among the arbic countries and was attractive to write about Egypt , and the country try to imprve itself but that will take alot of time (Böcker,2019).

The aim of the research - after assessing the business environment in the country to identify links with international labor migration.

Objectives of the research

1. Assess the business environment of selected countries.

2. Examine general migration and business trends in selected countries.

3. To identify the links between international labor migration and business environment.

Hypotheses

H1 - Immigration flows are related to the growing the number of enterprises registered over the year.

$\mathrm{H} 2$ - Emigration tendencies are related to the turnover of enterprises.

Research methods. A quantitative method was chosen for the research. For the assessment of the business environment in the country and identifying links with international labor migration, statistic and expert assessment methods, supplementing each other were applied.

Survey sample. In order to select scientifically based indicators, an expert survey was conducted according to the prepared expert evaluation questionnaire (Appendix 1). The main criteria for selecting experts are their qualifications and professional experience. 9 experts agreed to take part in the research. Five of them represent a scientific institution, four experts have set up their own businesses. The average work experience of the interviewed experts is 15 years. 
Research organization. In the first stage, having summarized and analyzed the impact of international labor migration on business activities, for the business environment assessment five external factors - economic, institutional, social, cultural and technological have been distinguished. 7 indicators have been allocated for the economic factors, 6 indicators for institutional and cultural factors, 9 indicators for the social one, and 8 for technological one.

Experts were surveyed in order to find out if the selected external factors and indicators are relevant, if the indicators really belong to the allocated factor, if any significant indicators have been missing and how meaningful they are. The experts, who agreed to take part in the research, assessed external factors and indicators ranking them in accordance with their significance. The weight coefficient of every factor and indicator $\left(W_{f}\right)$ are estimated under the following formula:

$$
W_{f}=\frac{\overline{S_{1}}}{\sum_{i=1}^{n} \bar{S}}
$$

where: $\bar{S}_{1}$ - statistic average;

$\sum_{i=1}^{n} \bar{S}$

- is a sum of statistic averages/means.

In order to assess the business environment of the selected countries and to determine the most attractive country for business activities, an index of business environment was created:

$$
I_{B E}=\sum_{i=1}^{i=36} x \cdot y \cdot j
$$

where: $x$ is the expert weight of the dimension;

$y$ is the indicator weight (significance);

$j$ Min-Max index is estimated under the formula:

$$
j=\left(r_{-} f-r_{-} \min \right) /\left(r_{-} \max -r_{-} \min \right)
$$

where: $r_{-} f$ is the real meaning of the indicator;

$r \_$minand $r \_$max are minimal and maximal meaning of the indicator.

For country having the lowest value of this indicator the meaning is closer to 0 and for the country having the highest value of this indicator the meaning is closer to 1 . The maximum value means a better business environment. The weight of each indicator is initially being assessed by multiplying the significance coefficient of each factor by the significance coefficient of indicator obtained by survey of 9 experts. For each indicator the weight in percentage is being evaluated by dividing its initial significance in percentages from total initial significance of all indicators in percentages.

In the second stage, based on the performed assessment, the business environment in Egypt and Lithuania is compared. In the third stage the links between international labor migration and a business environment is identified.

\section{Results and Discussion}

Having summarized the experts' point of view, it has appeared that weights, allocated to every factor differ slightly (Table 2). 
Table 2. Expert 's opinion related to the meaningfulness of factors and indicators

\begin{tabular}{|c|c|c|c|}
\hline Factors & $\begin{array}{l}\text { Factors } \\
\text { weight }\end{array}$ & Indicator & $\begin{array}{l}\text { Indicator } \\
\text { weight in the } \\
\text { factor }\end{array}$ \\
\hline \multirow[t]{9}{*}{ ECONOMIC FACTORS } & \multirow[t]{9}{*}{0.2116} & Gross domestic product per capita, billion Eur $\left(e_{-} 1\right)$ & 0.1450 \\
\hline & & Foreign direct investment, billion Eur $\left(e_{-} 2\right)$ & 0.1450 \\
\hline & & Average earnings (annual gross), Eur $\left(e_{-} \_3\right)$ & 0.1603 \\
\hline & & The interest rate, $\%$ & 0.1450 \\
\hline & & $\left(e_{-} 4\right.$ & \\
\hline & & ) & \\
\hline & & Inflation, \% (e_5) & 0.1450 \\
\hline & & Exports, thousand. Eur $\left(e_{-} 6\right)$ & 0.1336 \\
\hline & & Imports, thousand. Eur $\left(e_{-} 7\right)$ & 0.1260 \\
\hline \multirow[t]{6}{*}{ INSTITUTIONAL FACTORS } & \multirow[t]{6}{*}{0.2222} & Voice and Accountability $\left(i_{-} \_1\right)$ & 0.1583 \\
\hline & & Political Stability and Absence of Violence (i_2) & 0.1625 \\
\hline & & Government Effectiveness $\left(i \_3\right)$ & 0.1792 \\
\hline & & Regulatory Quality (i_4) & 0.1667 \\
\hline & & Rule of Law (i_5) & 0.1667 \\
\hline & & Control of Corruption (i_6) & 0.1667 \\
\hline \multirow[t]{9}{*}{ SOCIAL FACTORS } & \multirow[t]{9}{*}{0.1852} & Average annual population, thous. $\left(s_{-} 1\right)$ & 0.1288 \\
\hline & & Live births, people $\left(s \_2\right)$ & 0.1135 \\
\hline & & Deaths, people $\left(s_{-} 3\right)$ & 0.0951 \\
\hline & & Indexes of ageing at the beginning of the year $\left(s_{-} 4\right)$ & 0.1104 \\
\hline & & Emigrants, people $\left(s \_5\right)$ & 0.1012 \\
\hline & & Immigrants, people $\left(s_{-} 6\right)$ & 0.1012 \\
\hline & & Educational attainment of the population, thous. $\left(s_{-} 7\right)$ & 0.1135 \\
\hline & & Unemployment rate, $\%\left(s_{-} 8\right)$ & 0.1135 \\
\hline & & Self-employed persons $\left(s_{-} 9\right)$ & 0.1227 \\
\hline \multirow[t]{6}{*}{ CULTURAL FACTORS } & \multirow[t]{6}{*}{0.1799} & Power distance index (PDI) $\left(c \_1\right)$ & 0.1840 \\
\hline & & Individualism vs. collectivism (IDV) $\left(c_{-} 2\right)$ & 0.1745 \\
\hline & & Uncertainty avoidance (UAI) $\left(c_{-} 3\right)$ & 0.1698 \\
\hline & & Masculinity vs. femininity (MAS) $\left(c_{-} 4\right)$ & 0.1604 \\
\hline & & Long-term orientation vs. short-term orientation (LTO) $\left(c_{-} 5\right)$ & 0.1557 \\
\hline & & Indulgence vs. restraint (IND) $\left(c_{-} 6\right)$ & 0.1557 \\
\hline \multirow[t]{8}{*}{$\begin{array}{l}\text { TECHNOLOGICAL } \\
\text { FACTORS }\end{array}$} & \multirow[t]{8}{*}{0.1958} & $\begin{array}{l}\text { Enterprises using information and communication technologies, \% } \\
\left(t_{-} 1\right)\end{array}$ & 0.1401 \\
\hline & & Share of the turnover of innovative products, $\%\left(t_{-} 2\right)$ & 0.1276 \\
\hline & & Innovation expenditure as a percentage of total turnover, $\%\left(t_{-} 3\right)$ & 0.1276 \\
\hline & & $\begin{array}{l}\text { Expenditure on innovation activities of technological innovation } \\
\text { enterprises, mln. Eur }\left(t_{-} 4\right)\end{array}$ & 0.1245 \\
\hline & & R\&D expenditure, compared to GDP, \% $\left(t_{-} 5\right)$ & 0.1152 \\
\hline & & $R \& D$ expenditure, mln. Eur $\left(t_{-} 6\right)$ & 0.1120 \\
\hline & & $\begin{array}{l}\text { Use of e-commerce for private purposes, All persons aged } 16-74- \\
100 \text { per cent }\left(t_{-} 7\right)\end{array}$ & 0.1276 \\
\hline & & Households having personal computers, Internet Access, \% $\left(t_{-} 8\right)$ & 0.1245 \\
\hline
\end{tabular}

As it can be seen from Table 6, the experts have allocated the highest weight to the institutional factors $(0.2222)$, and the least -0.1799 - to cultural factors.

\subsection{The Economic Indicators of Egypt}

Gross domestic product (GDP) and foreign direct investment. The foreign direct investment rate in Egypt is decreased and that is because the Egyptian government increasing the interest rate on loans and increasing the taxes, they will decrease the desire of the foreign and national investment. The GDP in Egypt was affected negatively and decreased, because the high rate of taxes that the Egyptian government imposed it on the national and international enterprises in Egypt. the high taxes rate in Egypt made the production of the different goods and products get decreased because most investors escape from Egypt and make other investments in other 
countries and that made Egypt depend on the importing activities more than depending on the production. The decreased production activities increase migration rate of the skilled workers in Egypt which that made the productivity rate in Egypt get decreased from time to time (Angel, 2006).

\subsection{Institutional Factors}

Political Stability and Absence of Violence and control of corruption and government effectiveness in Egypt. The political stability in Egypt was unstable and cannot positively support the business environment in Egypt because all foreign and national investors want to make sure that their enterprises is safe from political corruption of the government of the host countries and the government of the host countries could use their authorities power to steal from the profit of the international and the national enterprises and to be a compulsory business partners with them. When a country has a political corruption that will mean that the imposed taxes will be high by the government and there will be no enough subsidies provided by the government because the official of the government are corrupted (Böcker,2019).

\subsection{Social Factors}

The Migration in Egypt is strongly influenced by poverty, economic difficulties, and improper socio-economic policies. Until the mid-1950s, foreigners came to Egypt but Egyptians rarely migrated abroad (Aleksynska\& Tritah,2006). Egyptian emigration was not only a reflection of the oil boom in the European countries and in Arab Gulf countries and the need for manpower in neighboring countries in mid-1970s, but also of economic difficulties and high rates of population growth in Egypt in the second half of the 20th century. Rapid population growth is one of the crucial problems that have hindered development efforts in Egypt. While the doubling of Egypt's population between 1897 and 1947, from 9.7 million to 19 million, took fifty years, the next doubling took less than thirty years, from 1947 to 1976. Associated with rapid population growth is a high level of unemployment. Current official unemployment rate in Egypt is about 10 percent, but independent estimates push the rate up to 20 percent (Collier, P., \& Hoeffler, 2018). During the Covid19 that indicate that Egypt in the COVID-19 crisis may lead to a 1.1 percent decline in Egypt's GDP during the 4th quarter (April to June) of the 2019/20 fiscal year, compared to the same quarter in 2018/19 (Bratsberg et al., 2007).

\subsection{Technological Factors}

Information and Communications Technology (ICT) sector in Egypt is high, with a growth rate higher than Egypt's level of GDP growth. Its contribution to the GDP has increased to 4\% in 2019 compared to $3.5 \%$ in 2018. Total investments in the sector increased by 24.3 percent in 2019 and reached $\$ 107$ million in the first quarter of 2020. Under its ICT 2030 strategy, the Egyptian government is undertaking a series of investments, capacity building and training programs, digital government services reforms, and infrastructure upgrades. The strategy calls for launching new initiatives to maximize the contribution of the ICT sector to Egypt's economic growth by focusing on capacity building, electronics design and manufacturing, and technology parks (Chami et al 2003). The strategy also includes a plan for the digital transformation of core government services in the following areas: education, healthcare, and government services. The New Administrative Capital (NAC), 50 miles east of central Cairo, is expected to eventually house the majority of central government offices, with a target moving in date of June 2021. The government is planning for the NAC to be a "Smart City," and is investing heavily in the new city's telecommunications and ICT infrastructure. Under the plan, a "Knowledge City," which will be located inside the NAC, will include applied research centers for technology to facilitate technical training, software and applications development, and data design. The Knowledge City is estimated to cost a total of 12 billion Egyptian Pounds (\$750 million). Due to the Covid-19 outbreak, Egypt has witnessed the acceleration of its digital transformation plan. The number of peak hours for internet usage has increased to 15 hours per day from 7 hours per day and the load has increased by $99 \%$. The amount of cellular phone internet usage has increased by $35 \%$, and international calls by $19 \%$. Some applications witnessed a significant increase of usage like: Zoom App 3465\%, Telegram 1100\%, and YouTube 115\% (Clark, et al, 2007).

\subsection{Cultural Factors of Egypt}

Egypt scores high on the dimension of power distance (score of 70) which means that people accept a hierarchical order in which everybody has a place and which needs no further justification. Hierarchy in an organization is seen as reflecting inherent inequalities, centralization is popular, subordinates expect to be told what to do and the ideal boss is a benevolent autocrat. Egypt is considered a collectivistic society, hiring and promotion decisions take account of the employee's in-group; management is the management of groups. Egypt scores 80 on this dimension and thus has a high preference for avoiding uncertainty (Collier\& Hoeffler,2019). security is an important element in business activities. Egypt has a very low score of 7 indicated that its culture is very normative. People in such societies have a strong concern with establishing the absolute Truth; they are 
normative in their thinking. They exhibit great respect for traditions, a relatively small propensity to save for the future, and a focus on achieving quick results (Collyer, 2006).

\subsection{The Economic Indicators of Lithuania}

The gross domestic product. (Cazzuffi, \& Modrego, 2018), There was a rise in the minimum wage and the tight labor market condition should lead wages up. In 2019 Lithuanian exports totaled EUR 14 billion, and imports reached EUR 12.3 billion. Compared to 2018, exports and imports grew by $4.7 \%$ and $2.8 \%$, respectively. Lithuania demonstrated remarkable resilience to the global economic slowdown in 2019: Lithuania's GDP grew by $3.9 \%$, compared to growth of just $1.5 \%$ in the European Union. (Bratsberg et al, 2007).

\subsection{Institutional Factors}

Political Stability and Absence of Violence and control of corruption and government effectiveness in Lithuania. The involvement of the Lithuania government in international agreements are very important factors for improving and protecting the security and the interest of the foreign entrepreneurs in Lithuania from all kinds of corruption of the officials of the government of Lithuania. The government of Lithuania has the accountability of providing National policy guidelines and high quality of laws that can regulate all trade activities and all the trade conflicts that could occur in Lithuania; representatives of the same political power in both local and national government; must encourage all media in Lithuania to display all the advantages of Lithuania business environment which that in the end will encourage the foreign investors to invest in Lithuania. The Lithuanian government must fight and control all kinds of corruption in the Lithuanian government and that inspecting all the different activities of the officials in the Lithuanian government (Cooray, \& Schneider, 2016).

\subsection{Technological Factors}

Lithuania has become a regional center of excellence for global technology companies looking to harness the quality competences the country has to offer - whether it's in the fields of software engineering, AI-driven solutions, fintech product development or compliance \& AML. And the sector is not only rich in expertise, it's also a hub of innovation. Lithuania has one of the fastest growing startup ecosystems in the regionLithuania allocated a big portion of its budget to improve the technology sectors to be in the same level of the other European countries. (Cornelius\& Tsuda, 2004).

\subsection{Cultural Factors}

Lithuania owns a low score on the power distance dimension (42), Lithuanians prefer equality and a decentralization of power in decision-making process. Lithuania is an Individualist country and it achieved a score of 60 . The ideal of a nuclear family has always been strong and close family members are usually regularly in touch, (Cowen, 2019). Although the Lithuanians are considered a relatively reserved culture, they are tolerant towards the culture of other nations. Lithuania achieved a score of 65 on this dimension there is an emphasis on Uncertainty Avoidance. Lithuanians are worry from the world around them. In the work environments of countries with a low Uncertainty Avoidance, one can be a good manager without having precise answers to most questions that subordinates may raise about their work. Lithuanian culture is one of Restraint. Societies with a low score in this dimension have a tendency to cynicism and pessimism. (Cazzuffi, \& Modrego, 2018).

\subsection{Social Factors}

Annually, many persons come for staying in Lithuania from many countries of the world. Some of them come to study, or to work or to build their own business in Lithuania, other intend to join their families and so on. The principal bases of immigration to Lithuania include: family reunification, employment, business, studies and so on. Migration to Lithuania started to flourish enterprises and organizations and the economy of Lithuania and fill the labor shortages in all business departments. The principal immigration-related requirements in Lithuania depend on attracting a huge amount of a skilled labor from many different countries around the whole world set for such persons include high qualification, based on a diploma of higher education, and the agreed salary that should be no less that the salary established in the legal norms and that will increase the productivity rate in Lithuania and that also will increase the national income in Lithuania (Collyer, 2006).

\subsection{Evaluation of Research Results}

The economic and institutional and cultural and indicators of Lithuania are stronger and more attractive for foreign investors than the same indicators of Egypt.

The analysis of the business environment allows us to assume that a business-friendly environment not only attracts more immigrants to the country, but is also related to the business activities in that country. It is necessary to pay attention to the fact that after evaluating of business environment there was also carried out a 
correlative analysis. The estimated correlative coefficients and $p$ meanings revealed that there is a strong reciprocal relation among some indicators.

The calculation of the correlation coefficients in Egypt showed that a statistically significant relationship is between immigration and the number of enterprises registered over the year $(\mathrm{r}=0,890, p<0,05)$, also a statistically significant relationship is between immigration and turnover of enterprises $(\mathrm{r}=0,942, p<0,05)$ (Table 3).

Table 3. Relationship between business activities and migration in Egypt

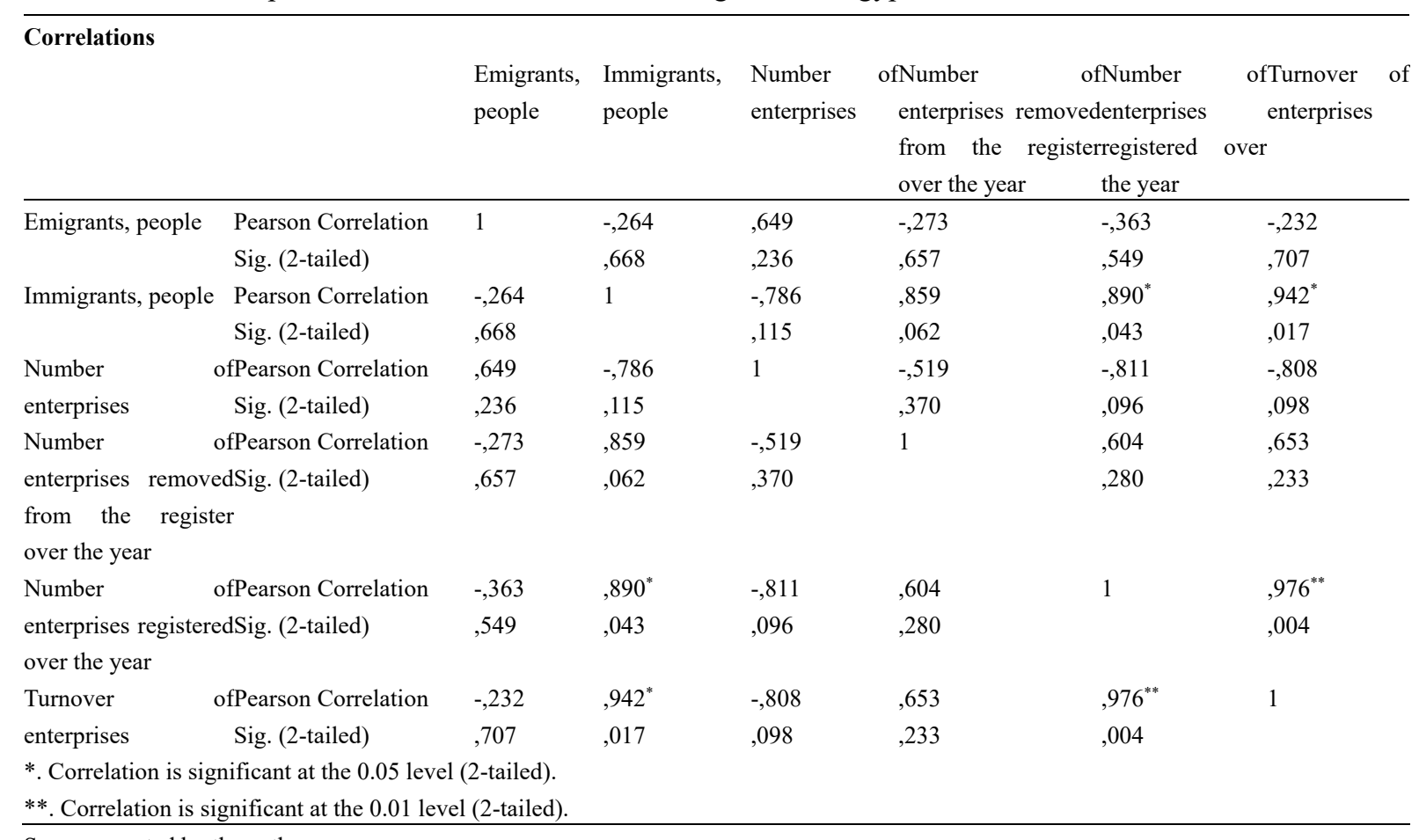

Source: created by the author.

As it can be seen from the Table 11, the correlations coefficients are 0,890 and 0,942 ; this indicates a strong direct dependence - as immigration flows increase, the number of registered enterprises increases. Figure 5 shows that immigration flows determine the number of registered enterprises as high as 79.3 percent.

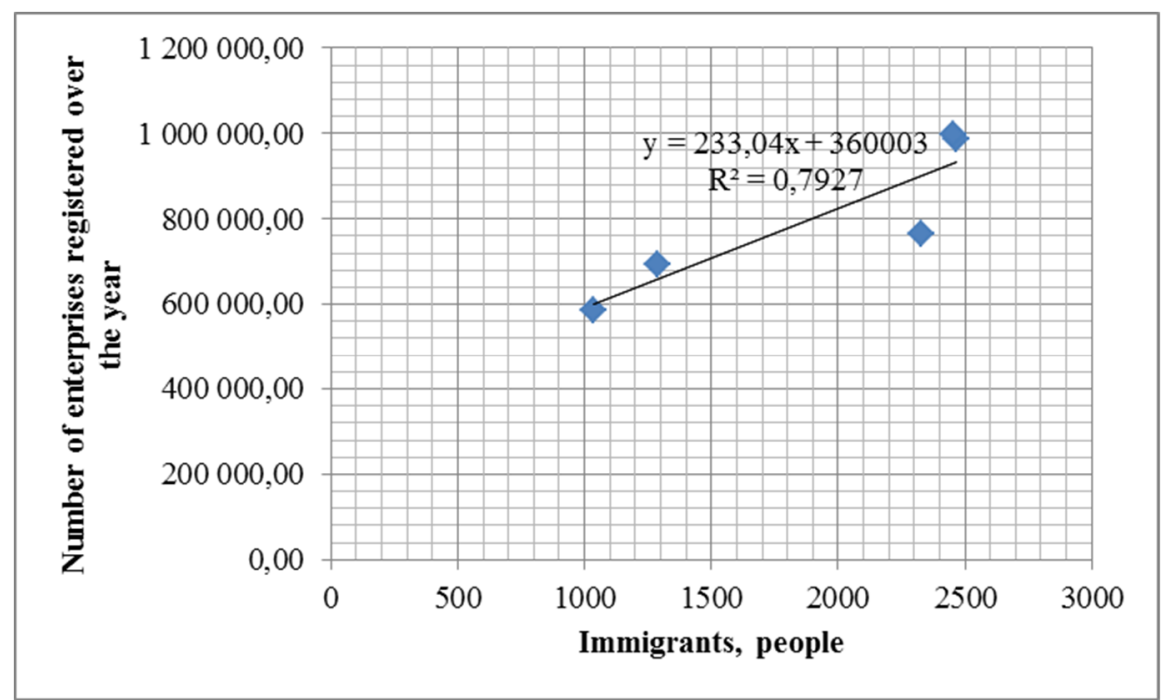

Figure 4. The links between immigration and the number of enterprises registered over the year in Egypt 
The estimated correlative coefficients and $\mathrm{p}$ meanings revealed that in Lithunia also strong statistically significant relationship is between immigration and the number of enterprises registered over the year $(\mathrm{r}=0,942$, $p<0,05)$, relationship between immigration and turnover of the enterprises exists but is not statistically significant (Table 4).

Table 4. Relationship between business activities and migration in Lithuania

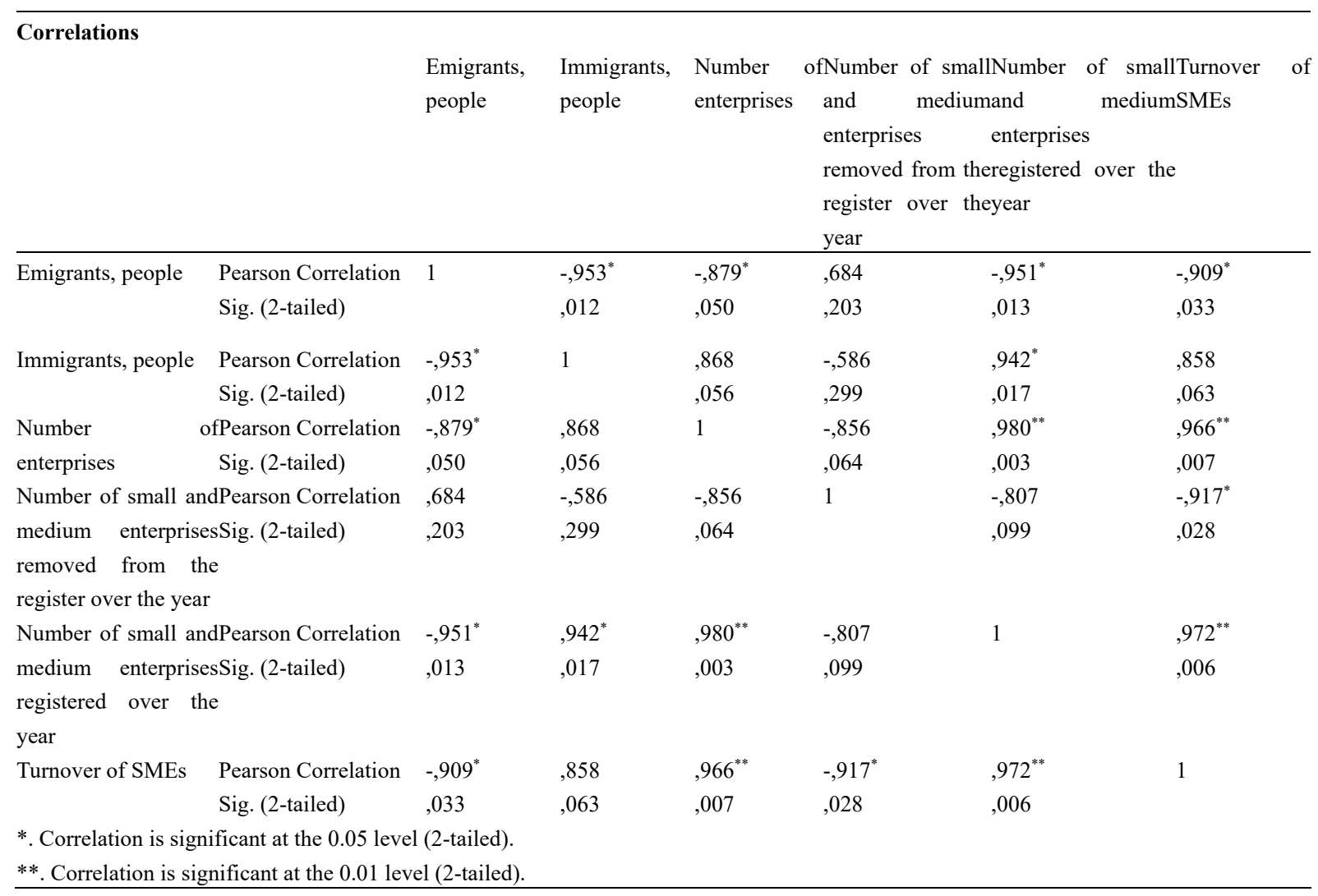

Figure 5 shows that immigration flows in Lithuania determines the number of small and medium enterprises registered over the year as high as 88.7 percent.

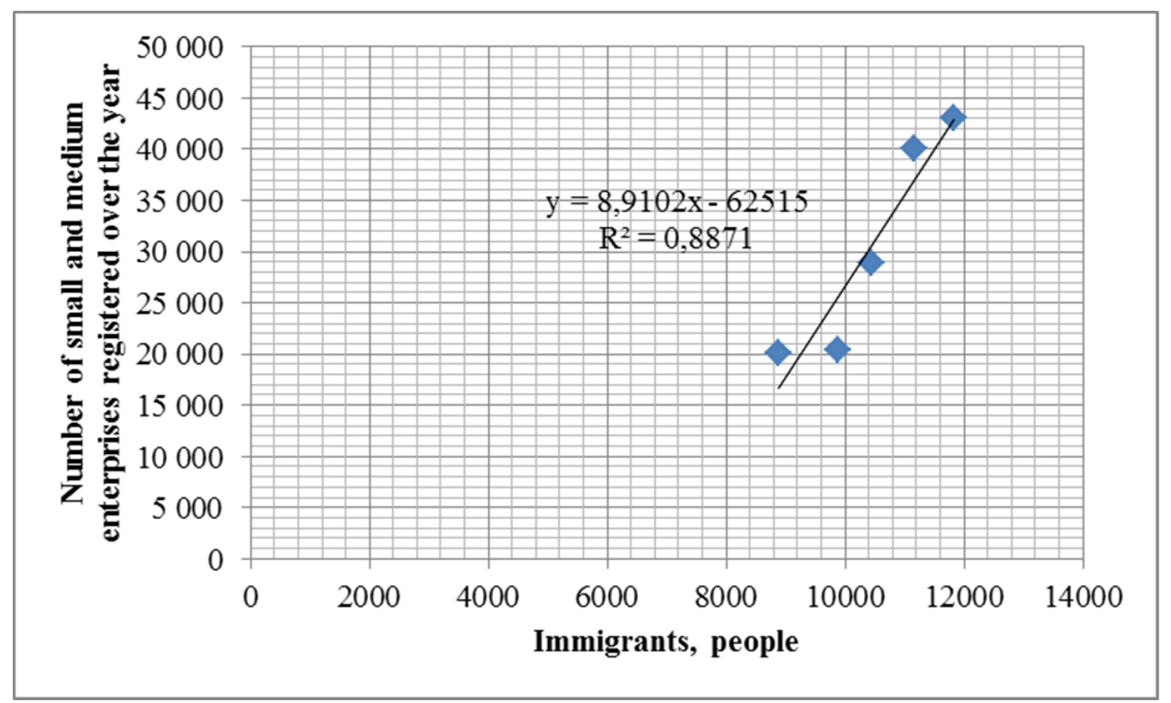

Figure 5. The links between immigration and the number of enterprises registered over the year in Lithuania 
In summary, it can be stated that hypothesis $H 1$ - Immigration flows are related to the growing the number of enterprises registered over the year - was confirmed, because in both Egypt and Lithuania a strong statistically significant relationship was found between immigration and the number of enterprises registered over the year.

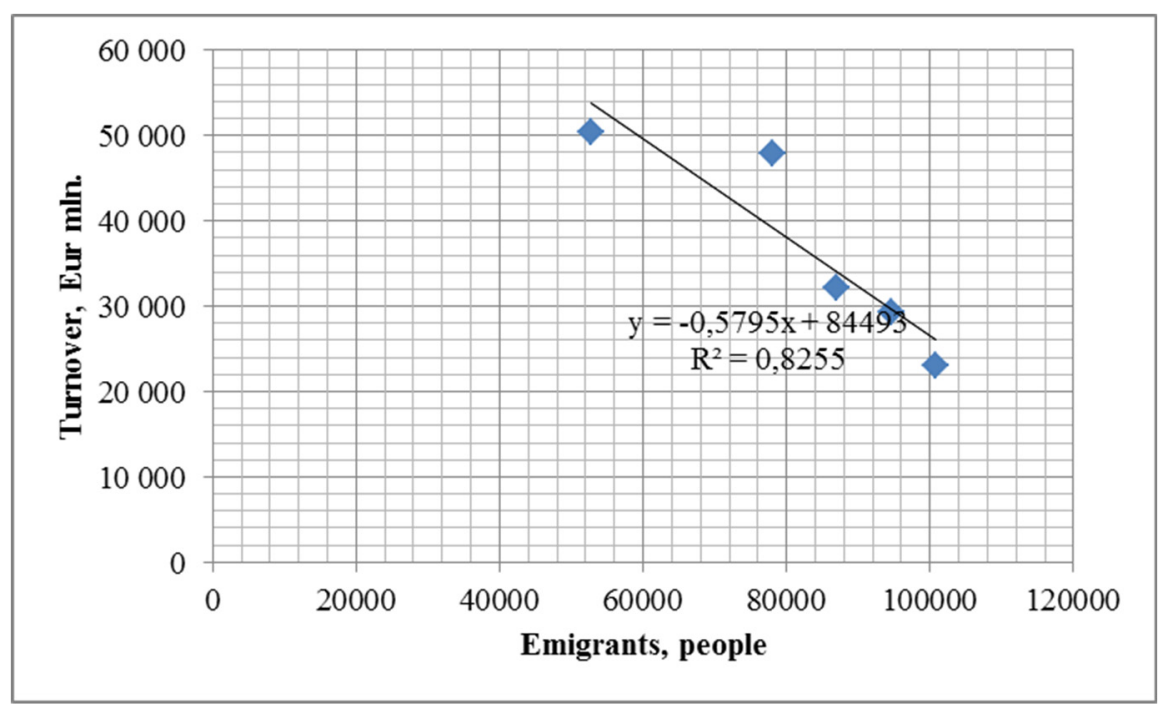

Figure 6. The links between emigration and the turnover of enterprises in Lithuania

Figure 6 shows that emigration flows determine the turnover of enterprises in Lithuania as high as 82.6 percent. The correlation coefficient is $-0,909$, this shows a very strong inverse relationship: as emigration flows increase, the turnover of enterprises decreases.

Examining the situation in Egypt (Table 3), the relationship was found to be reverse, but weak and statistically insignificant. This result may have been due to the fact that the flows of emigrants in this country are lower than those of immigrants, therefore the impact on the country's business is felt to a lesser extent.

In summary, it can be stated that hypothesis $\mathrm{H} 2$ - Emigration tendencies are related to the turnover of enterprises - was partially confirmed, because in Lithuania a strong statistically significant relationship was found between emigration and the turnover of enterprises, however, no such link has been determined in Egypt.

\section{Conclusions}

1. The article provided an overview of the phenomenon of international labor migration, a phenomenon considered to be controversial due to its many implications (economic, demographic, social and political) in our lives and analyses the advantages and disadvantages of labor migration.

2. International labor migration is an increasingly important component of contemporary society, a factor driving market globalization, and a tool for regulating imbalances in markets.

3. International labor migration has a positive and negative consequences on the business of the origin countries, in which it make the origin countries are less favorable destination for the foreign investors, because the origin countries suffer from high rate international labor migration decrease productivity and profit rate, and make the original countries have weak currencies and weak international trade relation, and the positive impacts of international relation is represented in the making the destination areas have high productivity and strong currency and strong international trade relation with the other countries around the world.

4. The article provided the explanation of how businesses environment is considered very important for the different business activities, so if the business environment is suitable and stable that will increase the success of the different business activities, and if the business environment does not get any support from the government the economic and the cultural and the institutional and the social indicators of the business environment is not supportive for the business environment that will not the different business activities inside this business environment be successful.

5. The article provided the explanation of the links of the links between international labor migration and business activities, as migrant workers have impact on developing the economic growth of the host countries, 
which that will mean that when the percentage of the different business enterprises increased in a certain host country that will increase the desire of the migrant labor to migrate to this certain host country and if a certain country has unfavorable business environment that will stop the labor migration to this certain country. The impact of the migrant workers as major factor for improving the production outputs. All the economic and social and cultural and institutional must be very supportive to the business environment to make all business enterprises are very successful.

\section{References}

Abreu, A. (2018). The New Economics of Labor Migration: Beware of Neoclassicals Bear-ing Gifts. Forum for Social Economics, 41(1), 46-67. https://doi.org/10.1007/s12143-010-9077-2

Arango, J. (2000). Explaining migration: a critical view. International Social Science Journal, 52(165), 283-296. https://doi.org/10.1111/1468-2451.00259

Ahmed, F. Z. (2012). The Perils of Unearned Foreign Income: Aid, Remittances, and Gov-ernment Survival. American Political Science Review, 106(1), 146-165. https://doi.org/10.1017/S0003055411000475

Akerman, S. (2007). Theories and Methods of Migration Research. In H. Runblom \& H. Norman (Eds.), From Sweden to America: A History of the Migration. Minneapolis: Uni-versity of Minnesota Press. Available at: https://www.ilo.org/asia/publications/WCMS_534954/lang--en/index.htm

Angel, C. M. (2006). Mexico: Caught Between the United States and Central America. Migration Policy Institute. Retrieved from https://www.ilo.org/kathmandu/whatwedo/publications/WCMS_541231/lang--en/index.htm.

Aydemir, A., \& Robinson, C. (2020). Global Labour Markets, Return, and Onward Migra-tion. Canadian Journal of Economics, 41(4), 1285-1311. https://doi.org/10.1111/j.1540-5982.2008.00504.x

Aleksynska, M., \& Tritah, A. (2009). Immigration, income and productivity of host country: A channel accounting approach.

Böcker, A. (2019). Chain Migration over Legally Closed Borders: Settled Immigrants as Bridgeheads and Gatekeepers. Netherlands Journal of Social Sciences, 30(2), 87-106.

Borjas, G. J. (2019). Economic Theory and International Migration. International Migration Review, 23(3), 457-485. https://doi.org/10.1177/019791838902300304

Bratsberg, B., Raaum, O., \& Sørlie, K. (2007). Foreign-Born Migration to and from Norway. In Ç. Özden \& M. Schiff (Eds.), International Migration, Economic Development and Policy. New York: Palgrave.

Brücker, H., \& Schröder, P. J. H. (2019). Migration regulation contagion. European Union Politics, 12(3), 315-335. https://doi.org/10.1177/1465116511410749

Castles, S. (2003). Why Migration Policies Fail. Ethnic and Racial Studies, 27(2), 205-227. https://doi.org/10.1080/0141987042000177306

Cazzuffi, C., \& Modrego, F. (2018). Place of Origin and Internal Migration Decisions in Mexico. Spatial Economic Analysis, 13(1), 1-19. https://doi.org/10.1080/17421772.2017.1369148

Chami, R., Fullenkamp, C., \& Jahjah, S. (2003). Are Immigrant Remittance Flows a Source of Capital for Development? IMF Working Paper 03/189. https://doi.org/10.5089/9781451859638.001

Clark, X., Hatton, T. J., \& Williamson, J. G. (2007). Explaining US Immigration, 1971-1998. Review of Economics and Statistics, 89(2), 359-373. https://doi.org/10.1162/rest.89.2.359

Clemens, M. A. (2014). Does Development Reduce Migration? IZA Discussion Paper No. 8592. https://doi.org/10.2139/ssrn.2457264

Collier, P., \& Hoeffler, A. (2019). Migration, Diasporas and Culture: An Empirical Investigation. Unpublished manuscript. Retrieved from https://www.ilo.org/beirut/publications/WCMS_618158/lang--en/index.htm

Collyer, M. (2006). When Do Social Networks Fail to Explain Migration? Accounting for the Movement of Algerian Asylum-Seekers to the UK. Journal of Ethnic and Migration Studies, 31(4), 699-718. https://doi.org/10.1080/13691830500109852

Massey, D. S. (2004). Return Migration by German Guest workers: Neoclassical versus New Economic Theories. International Migration, 40(4), 5-38. https://doi.org/10.1111/1468-2435.00204

Cooray, A., \& Schneider, F. (2016). Does Corruption Promote Emigration? An Empirical Examination. Journal of Population Economics, 29, 293-10. https://doi.org/10.1007/s00148-015-0563-y 
Cornelius, W. A., \& Tsuda, T. (2004). Controlling Immigration: The Limits of Government Intervention. Stanford, CA: Stanford University Press.

Cowen, R. (2019). Global Diasporas: An Introduction. London: Routledge.

Damulienè, A. (2013). Migracijos problema Lietuvoje ir jos įtaka šalies ekonomikai.

\section{Copyrights}

Copyright for this article is retained by the author(s), with first publication rights granted to the journal.

This is an open-access article distributed under the terms and conditions of the Creative Commons Attribution license (http://creativecommons.org/licenses/by/4.0/). 